THURSDAY, MARCH 3r, I887

\section{A UNIVERSITY FOR LONDON}

$\mathrm{W}$

$E$ have from time to time informed our readers of the progress made in the attempt to organise the capacities for teaching and learning in London into a more complete and more efficient shape. The movement is most natural and admirable. What we have desired is to warn those interested in it not to lose sight of the full result obtainable while busied in their attempts to remove a particular grievance or further a particular interest. Each constituent of the future University-the Colleges and professional schools, the teachers and the students, the medical corporations, and the Senate and Convocation of the existing University of London-each is indispensable. Any one of these can block the way for the rest. Together they make up amply sufficient elements for the foundation desired, and this foundation would not be strengthened, but weakened, by attempts (which can never be realised) to bring in such heterogeneous elements as the British Museum or the Royal Society, the Government technical schools or the Corporation of the City and its Companies.

The present state of affairs is, we believe, pretty much as follows. The Convocation of the present University, in which the first efforts towards its reform began some six or seven years ago, rejected a scheme presented to it by a Committee of forty of its most distinguished members, of which Lord Justice Fry was the chairman. Among them were the present Home Secretary, the President of the Royal College of Surgeons, Mr. Justice Wills, Sir Joseph Lister, Dr. Wilks, Prof. Michael Foster, Dr. Bristowe, Mr. Power, Mr. Howse, Dr. Ord, Prof. Unwin, Mr. Thiselton Dyer, Mr. Anstie, Prof. Carey Foster, the Rev. Dr. Dale, and Mr. Cozens-Hardy. A second and much smaller Committee was then constructed by Mr. (now Sir Philip) Magnus, who had taken the lead in opposing some of the provisions of the previous scheme, and this Committee brought up, on report, a second and modified plan of reform, which passed Convocation last May, not without opposition, but by substantial majorities and with only minor alterations. This second Committee laid the amended scheme before the Senate and remain in charge of it. Meantime the Senate had appointed a Committee of its awn members, who have for several months been elaborating a scheme of their own, who have already conferred both with the Committee of Convocation and with one appointed by the Teaching University Association, and who have now presented their Report to the Senate. Some opportune vacancies, which occurred in the latter body during the last two or three years, have led to the presence of Lord Justice Fry himself, and of Dr. Wilks, Dr. Pye Smith, and Prof. Carey Foster. It seems probable that a scheme of reform will be accepted both by Senate and Convocation, which will go as far as most who are sanguine could expect, and farther than most who are timid will approve. The Convocation of graduates will gain more direct representation, and the teachers of the Colleges which send up men for the University degrees will probably be also directly reVOL. XxxV.-No. 909 presented on the Senate. But a more important improvement, one that would be useful even if the Senate were to remain exactly as it is, will almost certainly be the institution of Boards of Studies, which will represent the teachers and probably the examiners in each Faculty, much like the standing Committees which sit under the same name at Oxford. The general body of teachers which would elect these Boards would include provincial as well as London Professors, and would more or less correspond to the Congregation of Oxford, but it would probably seldom meet, except for the purpose of election of the representative Boards of Studies.

The Association for Promoting a Teaching University held a general meeting several weeks ago, and admirable speeches were made, especially those of Mr. Marshall and Mr. Bryce, but it lacked the enthusiasm given by numbers. After communicating with the principal London Colleges and Medical Schools, the Council of the Association propose to apply either to the Crown or to Parliament, probably with the object of securing a Royal Commission on the whole question.

University College, after coquetting with the Victoria University (which has apparently not welcomed with great warmth the proposal of accepting so large and distant a Society as its daughter), is now engaged in direct negotiations with King's College, with a view to agreement upon a common plan of action. This is a prudent course, for if the reform of the University of London should prove unattainable or inadequate, the two chief Colleges, by acting together, would be far more likely to obtain the privileges which they then would rightly seek.

Meantime the great medical corporations have become tired of waiting. They represent the most urgent grievance, and are fully justified in pressing for its redress. They appear likely to ask for power to grant degrees to their own licentiates, though under what authority and on what terms, either of examination or of residence, they have not yet determined. They have the advantage of practically undivided counsels, of knowing what they want, and of having an indisputable cause of complaint. They are naturally supported by the whole influence of the medical schools of London, and it adds not a little to the complexity of the situation that those connected with University and King's Colleges prefer to throw in their lot with the other professional schools rather than to hold aloof and unite with the other Faculties of their own Colleges.

Of the several bodies concerned, it is possible that the Senate, or at least the Convocation, of the existing University may fear that the just value of its degrees, attained by fifty years' efforts, will be compromised by allowing teachers to have a voice upon the Senate. But they must see that if the University is forsaken by its two most important London Colleges after the secession of its only important provincial one (Owens College), and if the medical schools of London, which have supplied nine-tenths of its graduates in that Faculty, also forsake it, its position will be untenable. Even if it were suffered to exist as a degree-conferring machine for unattached and imperfectly-taught students all over the kingdom, it would become what its worst enemies have called it, a mere Government Board, and could scarcely keep the title of a University, still less of the University of London, when it 
had been stripped (or rather had stripped itself) of both characters. Moreover, Convocation would lose all importance, and could not possibly retain the only powers it at present possesses, of nominating certain members of the Senate and accepting new charters. The Senate would do its sole work, of choosing examiners and revising their lists, as a small body of salaried Government officials (probably in South Kensington), and no claim would remain for the unconnected waifs and strays who passed the examinations to take any part in the matter. No charters would be requisite, nor any apparatus of library or Senate House, laboratory or lectures. In fact all the efforts of the past twenty years would be thrown away.

Nevertheless, if the two original Colleges of the University secede, they will find the name, the prescription and the influence of the Senate too strong for them to, wrest its powers from the present holders.

The medical corporations have far more influence and far stronger grounds; for the three or four strongest of them are organised as complete Colleges in their own Faculty, and give a more academic training to their students in medicine than either University or King's College does to students in arts, science, or laws. They might, perhaps, succeed in gaining power to grant degrees where the others failed, but this could only be by showing that no reasonable concessions were made to their just demands by the existing University.

Hence it will be seen that the present University of London, its two original Colleges, and the principal medical schools, have each of them the power of checking, if not of checkmating, each other's plans. Even if they agreed to urge their several objects without opposition to each other, the result would be three Universities existing together in London. One would have become a mere examining Government Board ; another would consist of two ill-endowed and ill-consorted Colleges, without residence, with slender endowments, and compelled to extend their proper functions by attempting the instruction of partial students; the third would be a combination of two large professional corporations with Colleges in one faculty only, two or three well equipped, several very poorly furnished, and all of necessity rivals, scattered over the country, none of them endowed, and only able by the terms of their existence to give a second-rate degree.

What hope would there be of any one of these three so-called Universities even approximating to what a University of London should be? Each would be strong enough to prevent the others succeeding; none would be strong enough to absorb its rivals. Meanwhile the higher education would deteriorate rather than improve, endowments would be indefinitely postponed, and the prospects of the University laboratories, museums, and libraries of London sending out worthy contributions to the progress of human knowledge would become poor indeed.

When the several separate movements now in progress are checked by the necessity of obtaining the sanction if not the support of Government, we may hope that broader views will be taken of what is best for the community, and more sober views of what is practically attainable. Believing in the public spirit and the good sense of our countrymen, we have little fear but that, with patience and mutual concessions, a combined result will be obtained which will benefit all the parties to the new confederation, and promote the only interests with which this journal is concerned-the national interests of learning and of science.

\section{A JUNIOR COURSE OF PRACTICAL ZOOLOGY}

A Junior Course of Practical Zoology. By A. Milnes Marshall, M.D., D.Sc., M.A., F.R.S., Professor in the Victoria University, assisted by C. Herbert Hurst. (London: Smith, Elder, and Co., I887.)

NOTICE will be found in the columns of this journal (vol. xxxiii. p. 242) of the second edition of a small laboratory hand-book by the senior author of the abovenamed work, entitled "The Frog; an Introduction to Anatomy and Histology." In the preface to that we read: "The second instalment of the work, containing directions for the examination and dissection of a number of animals chosen as types of the principal zoological groups, is in active preparation, and will be published shortly." The author further acknowledges "valuable help from Mr. C. H. Hurst, Assistant Lecturer in Zoology in the College." Mr. Hurst now appears as junior author, and, although the work here under review differs in some important respects from its predecessor above referred to, we presume that it is the promised "second instalment."

The volume opens with an introduction, confined to the consideration of practical hints as to methods of working and manipulation; then follow fifteen chapters, each devoted to some one type of organisation, and the whole closes with an appendix, dealing with the uses and methods of preparation of reagents. We have, in all, a most successful and important book of 42 I pages.

The work is largely akin, in its more salient features, to many of its predecessors; but it stands alone in respect of certain methods of treatment, to wbich we shall refer duly. Thick type has been employed throughout for the various headings, and the authors adopt the plan, introduced in the aforenamed smaller work, of printing the directions for dissection in italics. In dealing with the complications of the vertebrate skeleton, they have availed themselves of the printer's art, by way of restricting descriptions of homologous sets of elements to corresponding and distinct types.

The introduction is a model of perspicuity, and so well set as to render it impossible for the veriest tyro to obtain anything but full benefit therefrom. The advice given is sound in the extreme, and such as could only have embodied the results of a long and well-tried experience. The directions for injecting blood-vessels are, perhaps, a little too elaborate, being worthy of the préparateur's art, rather than of the ordinary beginner; this, however, is a small defect on the right side. We note that under the section on microscopical examination all reference to the micrometer has been omitted. Directions for measuring objects under observation should certainly be added to the next edition.

The several chapters into which the book is subdivided differ most conspicuously from those of certain earlier works in the fact that the more general statements made are diffused throughout the whole, except so far as they serve to define an animal under consideration, or to set 